\title{
FEDERAL STATUTORY PROVISIONS RELATING TO PRICE SUPPORT FOR AGRICUL TURAL COMMODITIES
}

\author{
ROBERT H. SHIELDS*
}

$\mathrm{S}^{0}$

FAR during the war period, the demands for agricultural commodities and their products, of course, have generally outrun supplies. As a result of these war-time demands, prices for agricultural commodities have, in the main, been at or above the producer price-support levels established by the War Food Administration and the Department of Agriculture. But, as War Mobilization Director Byrnes has recently indicated, ${ }^{\mathbf{I}}$ supplies may soon exceed demands in the case of many commodities for which price support must be given. In order to sustain market prices and support levels under such conditions, ${ }^{2}$ greatly increased price-support activity will undoubtedly be required. ${ }^{3}$ Techniques will have to be developed for supporting the prices of many commodities for which, because of the exceptional present demands, very little price-support activity has heretofore been necessary, and many difficult problems of handling, storing, and disposing of the large stocks of commodities that will undoubtedly be acquired will have to be solved. The federal statutory provisions relating to price support for agricultural commodities, with which this paper deals, will thus be likely to have greatly increased significance in the near future and in the postwar period. ${ }^{4}$

* Solicitor of the United States War Food Administration and of the Department of Agriculture.

I Rep. to President by Director of War Mobilization, N.Y. Times, $\S$ I, p. 4I, cols. 7 and 8 (Sept. Io, 1944), 90 Cong. Rec., Sept. r2, I944, at $776 \mathrm{r}$.

2 For an excellent discussion of the forces which will affect the postwar trend of farm prices, see a recent paper entitled "Agricultural Prices Following World War II," by O. V. Wells, of the Bureau of Agricultural Economics, United States Department of Agriculture.

3 The War Mobilization Director's recent report to the President, referred to in note I, supra, states that ".... it is estimated that compliance with this [price support] commitment may require an appropriation of as much as $\$ 2,000,000,000$ in 1945."

4 The federal law which provides the basic authority for price support activities, which would involve consideration of the powers of the Commodity Credit Corporation, is not covered by this article. The discussion here given is limited to those federal statutory provisions which make price-supporting action mandatory or which direct the manner in which price-supporting action shall be carried out. Authority in federal law for carrying out price-support action through the Commodity Credit Corporation and other corporations preexisted the statutory provisions here discussed and, of course, was exercised prior to the enactment of these statutes. For discussions of the powers of the Commodity Credit Corporation, see Hearings before the Subcommittee of the House Committee on Appropriations on the Agriculture Department appropriation bill for $x 945,78$ th Cong., $2 \mathrm{~d}$ Sess. (1944) I250-1256, and Hearings before the 
The federal statutes dealing with price support for agricultural commodities fall into two main classes: First, there are the laws dealing directly with price-support operations and, second, there are the laws dealing indirectly with price-support operations. These latter laws operate in three ways: (I) They place limitations on the disposal of governmentowned or controlled stocks of agricultural commodities; (2) they regulate the marketing and affect the production of agricultural commodities; and (3) they encourage increased consumption of agricultural commodities.

The laws dealing directly with price-support operations tend to divide the agricultural commodities (some $I 66$ in all) into three groups: ( $x$ ) the so-called basic commodities, (2) the so-called Steagall commodities, and (3) other commodities. The basic commodities are corn, wheat, cotton, tobacco, rice, and peanuts for nuts. The Steagall commodities are those as to which the United States Secretary of Agriculture or War Food Administrator has requested an expansion of production for war purposes and has made public announcement to that effect under the provisions of the socalled Steagall Amendment. 6 The Steagall commodities are: Hogs, eggs,

Joint Committee on Reduction of Non-Essential Federal Expenditures (Byrd Committee), 78th Cong., Ist Sess. (1943), Part 8, 2488-2494. See Hearings before the House Committee on Banking and Currency on H.R. 2725, 78th Cong., Ist Sess. (I943) $27-63$, for a collection of legal materials, including the charter, relating to the Commodity Credit Corporation. For resumés of the Corporation's activities see Reports of President of Commodity Credit Corporation for fiscal years $1940-43$, inclusive.

5 While the basic commodity loan legislation (see note 9 , infra) and the Steagall Amendment (see note 6, infra), in enumerating the basic commodities, speak only of "peanuts," peanuts for oil have been consistently treated for price-support purposes as a nonbasic commodity. This distinction between peanuts for nuts and peanuts for oil is in accord with the Congressional intention. See, e.g., statements of Senator Russell and Representative Pace, 87 Cong. Rec., 9950, 991.5 (I941), made on the floor of the Senate and the House, respectively, in connection with their sponsorship of peanut loan legislation. The same distinction has been made for pricecontrol purposes. See note 24 , infra.

6 The so-called Steagall Amendment is as follows;

"Sec. 4. (a) Whenever during the existing emergency the Secretary of Agriculture finds it necessary to encourage the expansion of production of any non-basic agricultural commodity, he shall make public announcement thereof and he shall so use the funds made available under section 3 of this Act [funds which the Commodity Credit Corporation is authorized to borrow on the credit of the United States], or otherwise made available to him for the disposal of agricultural commodities, through a commodity loan, purchase, or other operation, taking into account the total funds available for such purpose for all commodities, so as to support, during the continuance of the present war and until the expiration of the two-year period beginning with the Ist day of January immediately following the date upon which the President by proclamation or the Congress by concurrent resolution declares that hostilities in the present war have terminated, a price for the producers of any such commodity with respect to which such announcement was made of not less than $9 \circ$ per centum of the parity or comparable price therefor. The comparable price for any such commodity shall be determined and used by the Secretary for the purposes of this section if the production or consumption of such commodity has so changed in extent or character since the base period as to result in a price out of line with parity prices for basic commodities. Any such commodity loan, purchase, or other operation which is undertaken shall be continued until the Secretary has given sufficient public announce- 
chickens (with certain exceptions) and turkeys, milk and butterfait, dry peas of certain varieties, dry edible beans of certain varieties, soybeans for oil, peanuts for oil, flaxseed for oil, American-Egyptian cotton, potatoes, and cured sweet potatoes. ${ }^{7}$ Among the I40 or so other agricultural commodities for which support prices have been announced are wool, naval stores, American hemp, sugar beets, sugarcane, black-eye peas and beans, certain fruits for processing, certain vegetables for processing, barley, grain sorghums, rye, Sea Island cotton, certain vegetable seeds, winter cover crop seeds, and hay and pasture seeds. ${ }^{8}$

The law provides ${ }^{9}$ that farm prices of the basic commodities shall be

ment to permit the producers of such commodity to make a readjustment in the production of the commodity. For the purposes of this section, commodities other than cotton, corn, wheat, tobacco, peanuts, and rice shall be deemed to be non-basic commodities." Act of July I, x94I as amended, 55 Stat. 498 (I94I), 56 Stat. 768 (I942), x5 U.S.C. $\$ 7 \times 3 a-8$ (a) (Supp. III).

The powers, functions, and duties of the Secretary of Agriculture under the amendment and under other statutes relating to price support for agricultural commodities were among those transferred to the War Food Administrator. See Executive Order No. 9334 of April I9, I943, 8 Fed. Reg. 5423 (1943).

7 See War Food Administrator's proclamation of May 4, I944, 9 Fed. Reg. 4837 (I944). Previous announcements were made by the Secretary of Agriculture on August 29, I94I, 6 Fed. Reg. 4644 (I94I), January I5, I942, 7 Fed Reg. 422 (I942), and November 28, I942, 7 Fed. Reg. 9986 (1942), and by the War Food Administrator on September 8, I943, 8 Fed. Reg. I2524 (I943).

${ }^{8}$ See War Food Administrator's announcement of I944 support prices, United States Department of Agriculture press release of March 4, I944, and Sen. Rep. No. 922, 78th Cong., 2d Sess. (r944) 69 .

${ }^{9}$ Basic commodity loan legislation is found in section 8 of the Stabilization Act of $1942,5^{6}$ Stat. 767 (I942), 50 U.S.C. App. $\$ 968$ (Supp. III), as amended by the Stabilization Extension Act of 1944 , Pub. L. No. 383,78 th Cong., 2 d Sess. (June 30,1944 ) $\$ 204$ as amended by the Surplus Property Act of r944, Pub. L. No. 457,78 th Cong., 2d Sess. (Oct. 3 , 1944) $\$ 37$, and in section 302 of the Agricultural Adjustment Act of 1938,52 Stat. 43 (I938), 7 U.S.C. \& I302 (r940). Section 8(a) of the Stabilization Act of $\mathrm{x} 942$, as amended, is as follows:

"Sec. 8. (a) The Commodity Credit Corporation is authorized and directed to make available upon any crop of the commodities cotton, corn, wheat, rice, tobacco, and peanuts harvested after December 3I, I94I, and before the expiration of the two-year period beginning with the' Ist day of January immediately following the date upon which the President by proclamation or the Congress by concurrent resolution declares that hostilities in the present war have terminated, if producers have not disapproved marketing quotas for such commodity for the marketing year beginning in the calendar year in which such crop is harvested, loans as follows:

"(I) To cooperators (except cooperators outside the commercial corn-producing area, in the case of corn) at the rate in the case of cotton of $92 \frac{1}{2}$ per centum [except with respect to cotton crops harvested after December $3 \mathrm{r}, \mathrm{x}_{943}$, but not with respect to cotton crops planted after x944, 95 per centum] and at the rate in the case of the other commodities of go per centum, of the parity price for the commodity as of the beginning of the marketing year;

"(2) To cooperators outside the commercial corn-producing area, in the case of corn, at the rate of 75 per centum of the rate specified in ( $x$ ) above;

"(3) To noncooperators (except noncooperators outside the commercial corn-producing area, in the case of corn) at the rate of 60 per centum of the rate specified in ( $x$ ) above and only on so much of the commodity as would be subject to penalty if marketed."

See note 26 , infra for a brief explanation of the meaning of "parity." . 
supported by producer loans at 90 per cent of parity in the case of corn, wheat, tobacco, rice, and peanuts for nuts, and $92 \frac{1}{2}$ per cent of parity in the case of cotton (except with respect to cotton harvested after 1943 but planted before 1945,95 per cent of parity ${ }^{\mathrm{T}}$ ). These loans must be continued for at least two years after the war. When acreage allotments and marketing quotas are in effect under the Agricultural Adjustment Act of I938, these rates are available only to cooperating farmers, and non-cooperators are entitled to loans only on that part of their production in excess of the quota and at only 60 per cent of the rate applicable to cooperators. In the case of corn outside the commercial corn-producing area ${ }_{2}{ }^{\mathrm{Ir}}$ the applicable loan rate to cooperators is only 75 per cent of the rate in the area, and no loans are required to be made to non-cooperators outside the area. The law also provides that none of the foregoing loans are required to be made if marketing quotas are proclaimed but are opposed by more than one-third of the farmers voting in the producer referendum. ${ }^{\mathbf{2}}$

The law as amended further provides that the loan rates referred to above are subject to such adjustment-not below 85 per cent of parity, however-as the President determines necessary "to prevent an increase in the cost of feed for livestock and poultry and to aid in the effective prosecution of the war." justed to 85 per cent of parity pursuant to this provision. The I 944 wheat loan rate, originally so adjusted to 85 per cent of parity, has now been restored to the go per cent level.

ro Section 37 of the Surplus Property Act of r944, note 9, supra, which increases the loan rate on the 1944 cotton crop from $92 \frac{1}{2}$ percent to 95 percent of parity, reads as follows:

"(a) Section 8(a)(I) of the Stabilization Act of I942, as amended (relating to loans upon certain agricultural commodities), is amended by striking out 'at the rate in the case of cotton of $92 \frac{1}{2}$ per centum' and inserting in lieu thereof 'at the rate in the case of cotton of 95 per centum.'

"(b) The amendment made by this section shall be applicable only with respect to crops harvested after December $3 I$, I 943 , but shall not apply to crops planted after I 944 . In the case of loans made under such section 8 upon any of the 1944 crop of cotton before the amendment made by this section takes effect, the Commodity Credit Corporation is authorized and directed to increase or provide for increasing the amount of such loans to the amount of the loans which would have been made if the loan rate specified in the amendment made by this section had been in effect at the time the loans were made."

II The commercial corn-producing area, as defined by section $301(\mathrm{~b})(4)(\mathrm{A})$ of the Agricultural Adjustment Act of $\mathrm{r}_{938} 8,7$ U.S.C. $\S \mathrm{r} 30 \mathrm{O}(\mathrm{b})(4)$ (A) (1940), includes all counties in which the average production of corn (excluding corn used as silage) during the ten calendar years immediately preceding the calendar year for which such area is determined, after adjustment for abnormal weather conditions, is four hundred and fifty bushels or more per farm and four bushels or more for each acre of farm land in the county. See also section $30 \mathrm{r}(\mathrm{b})(4)(\mathrm{B})$ of the act.

${ }_{12} 55$ Stat. 205 (I94I), 7 U.S.C. $\S$ I330(Io) (Supp. III), and 56 Stat. 767 (r942), 50 U.S.C. App. $\$$ g68(a) (Supp. III).

${ }^{13} 5^{6}$ Stat. 768 (x942), 50 U.S.C. App. $\$ 968$ (c) (Supp. III). 
Prices for some of the basic commodities have been supported at various levels by producer loans since I933. Since the enactment of the Agricultural Adjustment Act of 1938 , the law has specified the levels at which these loans should be made. The rate of price support has been changed by administrative or Congressional action from time to time. Soon after the war in Europe began, the Congress fixed the loan rates on commodities produced through the calendar year I946 at 85 per cent of parity. ${ }^{14}$ With the enactment of the Stabilization Act of 1942 , these rates were raised from 85 per cent to 90 per cent of parity and were made applicable for at least two years after the war. The loan rate on cotton was increased on June 30 , I944, by the Stabilization Extension Act of I944, to $92 \frac{1}{2}$ per cent of parity and, with respect to cotton in I944, as just indicated, was increased on October 3, ig44, by the Surplus Property Act of I944, to 95 per cent of parity. ${ }^{\mathrm{IS}}$ In addition, Congress has by the Stabilization Extension Act directed the President ${ }^{36}$ to take "all lawful action" through any agency of the government to assure to producers of the basic commodities the higher of (I) the parity price or (2) the highest price (adjusted for grade, location, and season) received between January and September, I942. $^{17}$

The provisions of the Stabilization Extension Act of 1944 have raised questions as to the status of the mandatory loan rates. The Congress had before it, while.the Stabilization Extension Act was being considered, a provision increasing the loan rates on all the basic commodities to 95 per

${ }^{{ }^{4}} 55$ Stat. 205 (I94I) as amended by 55 Stat. 860 (I94x), 7 U.S.C. $\$$ ×330 (Supp. III).

15 See notes 9 and ro, supra.

${ }^{16} \mathrm{This}$ requirement will be effective only through June 30 , 1945, unless the Stabilization Act of 1942 is further extended. See section 6 of that act, as amended by section 203 of the Stabilization Extension Act of r944.

${ }_{7}$ This provision is as follows:

"Sec. $3 . .$. The President, acting through any department, agency, or office of the Government, shall take all lawful action to assure that the farm producer of any of the basic agricultural commodities (cotton, corn, wheat, rice, tobacco, and peanuts) and of any agricultural commodity with respect to which a public announcement has been made under section 4 (a) of the Act entitled 'An Act to extend the life and increase the credit resources of the Commodity Credit Corporation and for other purposes,' approyed July I, I94I, as amended (relating to supporting the prices of nonbasic agricultural commodities), receives not less than the higher of the two prices specified in clauses ( $\mathrm{r}$ ) and (2) of this section (the latter price as adjusted for gross inequity)." Stabilization Act of $\mathrm{r}_{942}$, as amended by Stabilization Extension Act of 1944 , Pub. L. No. 383,78 th Cong., 2d Sess. (June 30, r944) $\$ 201(\mathrm{~b})$.

The prices specified in clauses $(r)$ and $(2)$ of the section are: $(r)$ the parity or comparable price (adjusted for grade, location, and season) for the commodity; or (2) the highest price received by producers for the commodity between January I and September $\mathrm{I}_{5}, \mathrm{r}_{942}$ (adjusted for grade, location, and season), or, if the market for the commodity was inactive during the latter half of such period, a price in line with the prices during such period of other commodities produced for the same general use. These prices appear in the Monthly Price Report of the Bureau of Agricultural Economics, Agricultural Prices, June 29, I944, 19-24. 
cent of parity. ${ }^{x}$ However, the legislation then enacted increased only the cotton loan rate and provided that the President should take all lawful action to assure to farm producers of the basic commodities not less than the prices just referred to. It seems clear that this general legislative direction to the President did not change the mandatory loan rates on basic commodities. These rates are specifically fixed by that statute at $92 \frac{1}{2}$ per cent of parity for cotton and 90 per cent of parity for the other basic commodities. Moreover, the mandatory loan rate with respect to cotton in I944 was increased to 95 per cent of parity by the Surplus Property Act of 1944 but the loan rates with respect to the other basic commodities were not changed. This view is further confirmed by the fact that the War . Food Administration has recently announced roo per cent of parity purchase programs, under certain conditions, with respect to cotton and wheat for the I944 crops, whereas the loan rates remain at the statutory levels. ${ }^{19}$

With respect to the Steagall commodities-hogs, eggs, chickens and turkeys, milk and butterfat, dry peas of certain varieties, dry beans of certain varieties, soybeans for oil, peanuts for oil, flaxseed for oil, AmericanEgyptian cotton, potatoes, and cured sweet potatoes-the law also provides for price support for at least two years after the war, at not less than $9 \circ$ per cent of the parity or comparable price. The provision just discussed ${ }^{20}$ which directs the President to take all lawful action to assure producers the higher of the parity price or the highest price (adjusted for grade, location, and season) received between January and September, I942, is also applicable to the Steagall commodities. ${ }^{2 r}$

The Steagall Amendment provides that, whenever during the existing

${ }^{28}$ See H. R. Rep. No. 1698, 78th Cong., 2d Sess. (1944) 26.

19 U.S. Department of Agriculture press release of September 24, 1944 .

${ }^{20}$ See note $x 7$, supra.

2x In general, in connection with this mandate to the President, the War Food Administration is taking all lawful action, within the limits of the funds available to it, to carry out the Congressional direction to assure the producers of the basic and Steagall commodities the prices referred to. Substantially all the three billion dollar borrowing power of the Commodity Credit Corporation is committed as a result of its current loan, purchase, and other operations, and price-support programs at higher than present levels could not be carried out unless considerable additional funds were made available by the Congress. When the borrowing power of the Commodity Credit Corporation was last increased ( 57 Stat. 566 , I5 U.S.C. $\$ 7 \mathrm{I} 3 \mathrm{a}-4$ [Supp. III]) which was before the enactment of the Stabilization Extension Act of I944, the need for additional funds to carry out this mandate obviously was not considered. The Congress has not had an opportunity since the enactment of the Stabilization Extension Act of r 944 fully to appraise the need for funds and to implement its direction to the President by providing necessary additional funds. No consideration is here given to the possible effect of this direction to the President upon ceiling prices established under the Emergency Price Control Act of 1942, 56 Stat. 23 (I942), as amended, 56 Stat. 767 (1942), 50 U.S.C. App. $\$ 901$ et seq. (Supp. III) and Pub. L. No. 383 , 78 th Cong., $2 d$ Sess. (June 30, 1944). 
emergency the Secretary of Agriculture ${ }^{22}$ finds it necessary to encourage the expansion of production of any non-basic agricultural commodity, he shall make public announcement thereof. Upon such finding and announcement, the Secretary is required to use Commodity Credit Corporation and other funds available to him for disposal programs, through a commodity loan, purchase, or other operation, so as to support at not less than the specified level the price for the producers of the commodity with respect to which the announcement was made. This specified minimum price-support level was originally 85 per cent of the parity or comparable price. Under the amendment as originally enacted, the Secretary - was required to continue the price support for any such commodity until he had given sufficient public announcement to permit producers to make readjustments in the production of the commodity. Just as the loan rate in the case of the basic commodities was increased from 85 per cent to 90 per cent of parity by the Stabilization Act of 1942 , so the minimum-support rate for Steagall commodities was increased by that act to not'less than $9 \circ$ per cent of the parity or comparable price. Also, the Stabilization Act of 1942 extended the duration of the support for Steagall commodities by providing that the support should continue for at least two years after the war.

There are several points to be noted as to the methods by which prices of Steagall commodities may be supported. The law provides that prices may be supported "through a commodity loan, purchase, or other operation." It leaves the particular method for administrative determination. A variety of support mechanisms have been employed-commodity loans, as in the case of I944 crop of American-Egyptian cotton, purchase programs, ${ }^{23}$ as in the case of eggs, and variations and combinations of these, as in the case of soybeans. Many of these operations have involved inventory takeouts, that is, commitments to processors or dealers to purchase inventories of commodities for which farmers were paid support prices or inventories of products, such as soybean oil and meal, made from commodities for which farmers were paid support prices.

In addition, the marketing level at which price-support mechanisms are operative is left to administrative discretion. Thus, the price-support

${ }^{22}$ Now War Food Administrator, see note 6, supra.

${ }_{23}$ Section $2(e)$ of the Emergency Price Control Act of I942, as amended by the Stabilization - Extension Act of 1944 , provides that, after June $3^{\circ}$, I945, no government corporation shall make any subsidy payments, or buy any commodities for the purpose of selling them at a loss and thereby subsidizing directly or indirectly the sale of commodities, unless funds for such purpose have been appropriated by Congress. Purchases made under price support programs designed primarily to obtain necessary agricultural production do not appear to come within this prohibition. 
mechanism may be operative at the farm level, the local market level, the sub-terminal or terminal market level, or at more than one level, depending upon what is administratively most practicable. In most cases, operations are carried out at more than one level. For example, with respect to the I943 crop of Irish potatoes, loans were made to producers and to dealers who paid support prices, and purchase programs were carried out at both levels.

It will be noted that the Steagall Amendment provides for price support at not less than the 90 per cent of the parity or comparable price level, and that it does not $f x$ the level, as does the loan legislation with respect to the basic commodities. In other words, the Steagall Amendment establishes only a floor-9o per cent of the parity or comparable price-below which a support mechanism may not operate, and leaves the way open for price support at a higher level if such action is necessary to get needed production. The levels of price support for Steagall commodities range this year from 90 per cent of parity for eggs and potatoes to about I30 per cent of parity for milk and butterfat. ${ }^{24}$ It follows from what has been said that the price support for Steagall commodities may vary from year to year or time to time, provided, of course, that at all times the pricesupport level is equal to at least 90 per cent of the parity or comparable price. In the case of soybeans, the support price was about Io5 per cent of the comparable price for the I942 crop, about IIo per cent of the comparable price for the $1943 \mathrm{crop}$, and is almost $\mathrm{r} 25$ per cent of the comparable price for the r944 crop. In the case of hogs, on the other hand, the trend of the support rate has been downward recently. Thus, while \$1 3.75 per cwt. was the support level announced for 200 to 240-pound hogs through September 30, I944, \$12.50 per cwt. was the level announced at the same time for the period beginning October I, I944.

And this brings us to another question concerning price-support operations for Steagall commodities: Must the support-price mechanism for a commodity be applicable across the board, so to speak, that is, to all grades and qualities of a commodity? Here again practical considerations have dictated the answer. The support-price mechanisms for Steagall commodities have been designed, to the fullest practicable extent, to support the prices for producers of the commodity as grown and normally marketed at any location and at any time. However, in some cases the administrative officials have determined that the most practicable way to accomplish this objective, taking into account all factors of production,

${ }_{24}$ Peanuts are in a special category. See note 5 , supra. The level of producer price support for 1944 crop peanuts, both for nuts and for oil, is close to Ioo per cent of the parity price of peanuts for nuts and about 200 per cent of the comparable price of peanuts for oil. 
storage, marketing, and so forth, is by supporting only certain grades or qualities of a commodity. For example, last year with respect to Irish potatoes loan rates were based on the percentage of U.S. No. I potatoes in the lot, and loan rates on U.S. No. 2 potatoes were stated in terms of a percentage of the U.S. No. I loan rate. It seems reasonable to conclude that, so long as the support program, to the fullest practicable extent, enables the producer to receive the support price for the commodity in the form or condition in which it is normally marketed by producers, the requirements of the Steagall Amendment are satisfied.

These quèstions concerning price-support operations for Steagall commodities suggest still another, namely: Under the Steagall Amendment is each individual farmer to be guaranteed the support price on each day that he markets the commodity? To assure the attainment of this objective, it would be necessary throughout the marketing season to have marketing and storage facilities adequate to handle all Steagall Amendment commodities at every point where such commodities are marketed by farmers. Experience demonstrates that facilities are not now available to this extent. Accordingly, as indicated above, the Department must do the best it can with the facilities available. Thus, where local storage facilities are inadequate, producer loan programs may be supplemented by purchase programs and by loans and purchases at subterminal and terminal market levels, all such operations being calculated to assure the announced support prices to farmers.

Still another question is the extent to which seasonal adjustments in support prices may be made. In the case of non-perishable commodities produced on an annual crop basis, supporting the price at the required level, as determined as of the beginning of the marketing year, meets the Department's obligations under the Steagall Amendment, since the bulk of such a commodity has been produced and is available for marketing at that time. This view of the requirements of the Steagall Amendment is consistent with the specific provisions of the basic commodity loan legislation, which fix loan rates for the basic commodities in relation to parity prices determined as of the beginning of the marketing year. In the case of commodities produced the year round, as well as other commodities, adjustments in the support price in order to reflect either normal or otherwise desirable seasonal variations in the prices received by farmers constitute reasonable action under the Steagall Amendment.

In brief, then, the Steagall Amendment requires that, to the fullest practicable extent, each farmer be given the opportunity to receive support prices for his production of Steagall commodities. This obligation of 
the Department under the Steagall Amendment was re-emphasized by the Congress in the Act of February 28 , $1944,{ }^{25}$ in which it was again declared to be the duty of the Department to carry out fully its commitments to producers under the Steagall Amendment.

There are two other matters which should be mentioned. First, that the Steagall Amendment provides for supporting Steagall commodities at parity prices or comparable prices, whichever are applicable with respect to the particular commodity. Parity price is, in brief, a price which will give to the commodity a purchasing power, in terms of articles ordinarily purchased by farmers, approximately equívalent to its purchasing power in a particular base period. ${ }^{26}$ The law provides that the comparable price for any commodity shall be determined and used if the production or consumption of the commodity has so changed in extent or character since the parity base period as to result in a price out of line with parity prices for basic commodities. Comparable prices have been established for soybeans, peanuts for oil, and dry peas, and support price operations based on comparable prices are now in effect with respect to these commodities. ${ }^{27}$

${ }^{25} 58$ Stat. 106 (I944), Pub. L. No. 240, 78th Cong., 2d Sess. (February 28, I944) $§ 2$, which reads as follows:

"In cases where producers have expanded or hereafter expand production of nonbasic agricultural commodities pursuant to any public announcement made under section 4 (a) of the Act entitled 'An Act to extend the life and increase the credit resources of the Commodity Credit Corporation and for other purposes,' approved July I, I94I, as amended, it shall be the duty of the Secretary of Agriculture or the War Food Administrator through loans, purchases, and other operations under such section 4 (a), to completely fulfill all commitments made to such producers. In order to carry out the purposes of this section, the Secretary of Agriculture or the War Food Administrator shall use such of the funds available for carrying out the provisions of such section $4($ a) as may be necessary, and such funds are hereby made available for such purpose."

${ }^{26}$ Section 301 (a) (r) of the Agricultural Adjustment Act of 1938,52 Stat. 38 (r938), 7 U.S.C. $\S \mathrm{IzOI}(\mathrm{I} 940)$ is as follows:

' 'Parity,' as applied to prices for any agricultural commodity, shall be that price for the commodity which will give to the commodity a purchasing power with respect to articles that farmers buy equivalent to the purchasing power of such commodity in the base period; and, in the case of all commodities for which the base period is the period August Igog to July Igr4, which will also reflect current interest payments per acre on farm indebtedness secured by real estate, tax payments per acre on farm real estate, and freight rates, as contrasted with such interest payments, tax payments, and freight rates during the base period. The base period in case of all agricultural commodities except tobacco shall be the period August Igog to July I9I4. In the case of all kinds of tobacco except Burley and flue-cured such base period shall be the period August rgrg to July rg29, and, in the case of Burley and flue-cured tobacco, shall be the period August I934 to July I939; except that the August I9r9-July I929 base period shall be used in allocating any funds appropriated prior to September I, I940."

See Sections 2 and 8e of the Agricultural Adjustment Act (1933), 48 Stat. 32 (1933), 49 Stat. 762 (1935), 7 U.S.C. $\$ 602,608 \mathrm{e}$ (1940). See also "Parity Prices: What They Are and How They Are Calculated" (Bureau of Agricultural Economics, June 30, I942), passim.

${ }^{27}$ See section 3(b) of the Emergency Price Control Act of 1942,56 Stat. 27 (1942), 50 U.S.C. App. $\$ 903$ (b) (Supp. III), which provides for the determination and use of comparable prices, 
A second matter to be noted is the kind of conditions which the law permits to be attached to price-support benefits. ${ }^{28}$ Here, too, the law is not explicit. The Steagall Amendment provides for continuing price support for a two-year period after the war, when the need for increased production will probably have decreased considerably. Since the purpose of the two-year provision was to enable farmers to readjust their production to normal by the close of the two-year period, it is reasonable to conclude that production-adjustment conditions related to changes in production needs may be imposed. ${ }^{29}$ This would make the position of the Steagall commodities comparable to that of the basic commodities, on which loans at the full rate are made only to cooperating producers when márketing quotas are in effect. Adequate notice of such conditions would be required, of course. Actually no such production-adjustment conditions have yet been imposed.

With respect to price support for agricultural commodities other than the basic commodities and the Steagall commodities, section 4 (b) of the Act of July I, I94I,,$^{30}$ declares it to be the policy of the Congress that lending and purchase operations of the Department shall be carried out so as to bring the price and income of the producers of non-basic nonSteagall commodities to a fair parity relationship with the basic and the Steagall commodities, to the extent that funds for such operations are available, after taking into account the operations with respect to basic

in lieu of parity prices, in connection with price ceilings on agricultural commodities and products thereof. Comparable prices for seventeen commodities, including soybeans, peanuts for oil, and dry peas, have been established pursuant to this provision. See Monthly Price Report of the Bureau of Agricultural Economics, Agricultural Prices, September 29, 1942, 26-29.

${ }^{28}$ Section $2(m)$ of the Emergency Price Control Act of 1942 , added by the Stabilization Extension Act of 1944 , provides that unauthorized conditions shall not be imposed on payments with respect to the production or sale of agricultural commodities or in contracts for the purchase of such commodities. However, conditions reasonably related to the objective of the particular program would seem to be authorized.

29 The Steagall Amendment originally provided that price support operations should be continued until producers were given sufficient notice to readjust their production. 55 Stat. 498 ( $(94 \mathrm{r})$. It still contains this provision, in addition to the provision that prices shall be supported for at least two years after the war. As amended by 56 Stat. 768 (I942), 15 U.S.C. \& 7 ז3a-8(a) (Supp. III).

${ }^{30}$ Section $4(\mathrm{~b})$ is as follows:

"Sec. 4(b) It is hereby declared to be the policy of the Congress that the lending and purchase operations of the Department of Agriculture (other than those referred to in subsection (a) ) shall be carried out so as to bring the price and income of the producers of non-basic commodities not covered by any such public announcement to a fair parity relationship with other commodities, to the extent that funds for such operations are available after taking into account the operations with respect to the basic commodities and the commodities listed in any such public announcement and the ability of producers to bring supplies into line with demand." Act of July $x$, I94I, 55 Stat. 498 (I94I), I5 U.S.C. $\$ 77^{2}$-8(b) (Supp. III). 
and Steagall commodities and the ability of producers to bring supplies into line with demand. To the extent practicable, the Department is carrying out this declared policy of the Congress.

As has been stated above, price-support programs for certain of these commodities are being carried out. These include programs for wool, naval stores, American hemp, sugar beets, sugarcane, black-eye peas and beans, certain fruits for processing, certain vegetables for processing, barley, grain sorghums, rye, Sea Island cotton, certain vegetable seeds, winter cover crop seed, and hay and pasture seed. These price supports range from about 90 per cent of parity in the case of the loan program for naval stores to about I30 per cent of parity in the case of sugar beets and wool and about 160 per cent of parity for raisins.

The support-price operations conducted by the Department with respect to the basic and non-basic commodities affect such a large proportion of the total agricultural economy, both in terms of value of the crops and in terms of the number of farmers producing these crops, that the effect of the action is to bring the price of other agricultural commodities in line with those with respect to which these supports are operative. In the absence of a price for commodities not subject to price-support operations comparable to the prices of the supported commodities farmers would, of course, tend to shift to the production of commodities which are supported.

A word may be said about special price-support provisions for three commodities, namely, milk, sugarcane and sugar beets. The Agricultural Marketing Agreement Act of 1937 , as amended, ${ }^{35}$ provides for the issuance, after public notice and hearing, of marketing orders which fix minimum prices for milk to producers. In general, the purpose of the law is to fix prices which will tend to assure to the producers of milk and its products a parity return, adjusted to such extent as is reasonable in view of feed prices and other economic factors. In the case of sugar beets and sugarcane, there is statutory provision in the Sugar Act of 1937 , as amended, ${ }^{32}$ for marketing quotas and allotments with respect to sugar and for condiditional payments to producers of beets and cane. In the present short sugar supply situation, however, the quota provisions of the act are not operative.

Of course, the laws forming the bases of price supports for agricultural commodities can be effective only within the limits of available funds.

${ }^{3 x} 50$ Stat. 246 (1937), 7 U.S.C. $\$ 608$ (c) (x940).

${ }^{32}$ 50 Stat. 903 (1937), 7 U.S.C. § rroo et seq. (1940), as extended by Pub. L. No. 345, 78th Cong., 2d Sess. (June 20, I944). 
There is annually available to the Department upwards of one hundred million dollars, appropriated by section 32 of the Act of August 24, I935, as amended, ${ }^{33}$ which may be used for supporting prices of agricultural commodities. Currently, and probably for some time yet to come, there will be money available for purchasing commodities for the armed services, lend-lease, and foreign relief. These purchases, besides meeting the needs for which the particular purchases are made, may be effectively utilized to support prices. A half-billion dollars of lend-lease funds have been earmarked for the procurement of agricultural commodities and foods produced in anticipation of lend-lease needs. ${ }^{34}$ Of course, the Commodity Credit Corporation, with a borrowing power of three billion dollars and a capital of one hundred million dollars, is the chief source of funds for price-support purposes. If price-support operations are to be continued for the two-year period after the war, as is now provided in the basic loan legislation and the Steagall Amendment-to say nothing of the possibility that the level and scope of price support may be legislatively increased and extended-greatly increased funds must be supplied. ${ }^{35}$ It will be seen, therefore, that the extent to which price-support operations are carried out after the war will depend largely upon the extent to which funds are supplied by the Congress.

The laws discussed above are those which directly affect price-support operations. As was indicated at the outset, however, there are, in addition to these, laws which have an indirect price-supporting effect. These latter laws include those which relate to the disposal of government-owned and controlled stocks of agricultural commodities, those which regulate the marketing and affect the production of agricultural commodities, ${ }^{36}$ and those which tend to encourage the consumption of agricultural commodities. ${ }^{37}$ Because of the close relationship between the restrictions upon

${ }^{33} 49$ Stat. 774 (1935), 7 U.S.C. § 61 $2 c$ (1940).

${ }^{34}$ See hearings before Subcommittee of the House Committee on Appropriations, 78th Cong., 2d Sess. (1944) on Foreign Economic Administration Appropriation Bill for 1945, "Reserve for Agricultural Revolving Fund" 201-208.

3s See Report to President by Director of War Mobilization, cited note I, supra, and quotation therefrom, note 3 , supra.

${ }^{36}$ See Title III, Subtitle B-Marketing Quotas, of the Agricultural Adjustment Act of 1938 , 52 Stat. 45 et seq. ( $\left(r_{93} 8\right)$, 7 U.S.C. \& 13 II et seq. ( $(940)$, as amended, 7 U.S.C. \& $13 \times 2$ et seq. (Supp. III); the Soil Conservation and Domestic Allotment Act, 49 Stat. $x_{4} 8$ et seq. (r936), I6 U.S.C. $\$ 590 \mathrm{~g}(\mathrm{a})-59 \circ \mathrm{q}(\mathrm{b})$ (1940), as amended, I6 U.S.C. $\$ 590 \mathrm{~h}$ (Supp. III); Agricultural Marketing Agreement Act of 1937, as amended, cited note 31, supra; Sugar Act of 1937, as amended, cited note 32 , supra.

${ }^{37}$ See section 32 of the Act of August 24, 1935, as amended, cited note 33, supra. 
the disposition of commodities and the direct price-support operations of the Department, a brief discussion of these restrictions is in order.

For the last three years there has been included in the annual agricultural appropriation act a proviso which prohibits, except as is indicated below, the disposition by the Commodity Credit Corporation of farm commodities at less than the parity or comparable price. ${ }^{38}$ Moreover, the Agricultural Adjustment Act of 1938 prevents the sale of government held cotton at a price below that sufficient fully to reimburse the United States for the total cost of the cotton, including all payments made with respect to the cotton by any of its agencies, and, in addition, limits the sale of such cotton to I,500,000 bales in any calendar year and 300,000 bales in any calendar month. ${ }^{39}$ By the provisions of the Surplus Property Act of 1944 approved October 3, I944, these same restrictions were made applicable to the disposition under that act of surplus farm commodities

${ }^{38}$ Items entitled "Commodity Credit Corporation" in Department of Agriculture Appropriation Acts, I943, Pub. L. No. 674, 77 th Cong., 2 d Sess. (July 22, I942), I944, Pub. L. No. 129, 78 th Cong., ist Sess. (July I2, 1943), and r945, Pub. $X$. No. 367 , 78th Cong., 2d Sess. (June 28,1944 ). The proviso in the 1945 appropriation act is as follows:

"Provided further, That none of the fund made available by this paragraph [for administrative expenses of the Commodity Credit Corporation] shall be used for administrative expenses connected with the sale of Government-owned or Government-controlled stocks of farm commodities at less than parity price as defined by the Agricultural Adjustment Act of I93 8 or the comparable price as provided by section 4 (a) of the Act of July I, I94I, as amended (I5 U.S.C. 7 $13 \mathrm{a}-8$ ); and the method that is now used for the purposes of Commodity Credit Corporation loans for determining the parity price or its equivalent for $\frac{7}{8}$-inch middling cotton at the average location used in fixing the base loan rate for cotton shall also be used for determining the parity price for $\frac{7}{8}$-inch middling cotton at such average location for the purposes of this proviso: Provided further, That the foregoing shall not apply to the sale or other disposition of any agricultural commodity substantially deteriorated in quality (or in the case of perishable fruits and vegetables if there is danger of deterioration or of accumulation of stocks) or sold for the purpose of feeding, or the extraction of peanut oil, or commodities sold to farmers for seed or for new or byproduct uses: Provided further, That no wheat or corn shall be sold for feed at a price less than the parity price of corn at the time such sale is made: Provided further, That in making regional adjustments in the sale price of corn or wheat in [sic] the minimum price need not be higher in any area than the United States average parity price of corn."

${ }^{39}$ Section $38 \mathrm{I}$ (c) of the act, 52 Stat. 67 (1938), 7 U.S.C. $\$ 138 \mathrm{I}$ (c) (I940). The provision is as follows:

"Sec. $38 \mathrm{I}$ (c) The Commodity Credit Corporation is authorized on behalf of the United States to sell any cotton of the 1937 crop so acquired by it, but no such cotton or any other cotton held on behalf of the United States shall be sold unless the proceeds of such sale are at least sufficient to reimburse the United States for all amounts (including any price-adjustment payment) paid out by any of its agencies with respect to the cotton so sold. After July 3I, I939, the Commodity Credit Corporation shall not sell more than three hundred thousand bales of cotton in any calendar month, or more than one million five hundred thousand bales in any calendar year. The proceeds derived from the sale of any such cotton shall be used for the purpose of discharging the obligations assumed by the Commodity Credit Corporation with respect to such cotton, and any amounts not expended for such purposes shall be covered into the Treasury as miscellaneous receipts." 
held by any agency of the federal government. In addition, that act provides that farm commodities cannot be sold pursuant thereto even at parity or comparable prices, if current prevailing market prices are higher. $4^{\circ}$

The provisions of law which have restricted the disposition of farm commodities by the Commodity Credit Corporation have, however, also contained certain exceptions from these restrictions. ${ }^{45}$ They permit the disposal of any commodity below the parity or comparable price, if it has substantially deteriorated in quality. And perishable fruits and vegetables may be sold below the parity or comparable price, if there is danger of deterioration or of accumulation of stocks. Also, wheat may be sold for feed at less than parity but not less than the parity price for corn. In addition, farm commodities may be sold below parity or comparable prices, if they are sold to farmers for seed or are sold for new or by-product uses or, in the case of peanuts, for the extraction of peanut oil.

The Surplus Property Act of 1944 also contains a significant exception to the restrictions applicable to the disposition of farm commodities. ${ }^{42}$ This exception relates to the disposition of farm commodities for export. Farm commodities designated as surplus under the Surplus Property Act of 1944 may be sold for export, subject only to the general provisions relating to the disposition of surplus property set forth in that act. The act also authorizes the Commodity Credit Corporation to dispose of or cause to be disposed of, for cash or its equivalent in goods or for adequately secured credit for export only and at competitive world prices, any farm commodity or product thereof. without regard to restrictions with respect to the disposal of commodities imposed upon it by any other law.

40 The provision of the act is as follows:

"Sec. 2I (c). Surplus farm commodities shall not be sold in the United States under this Act in quantities in excess of, or at prices less than, those applicable with respect to sales of such commodities by the Commodity Credit Corporation, or at less than current prevailing market prices, whichever may be the higher, unless such commodities are being disposed of, pursuant to this Act, only for export; and the Commodity Credit Corporation may dispose of or cause to be disposed of for cash or its equivalent in goods or for adequately secured credit, for export only, and at competitive world prices, any farm commodity or product thereof without regard to restrictions with respect to the disposal of commodities imposed upon it by any law: Provided, That no food or food product shall be sold or otherwise disposed of under this subsection for export ( $\mathrm{r}$ ) if there is a shortage of such food or food product in the United States or if such sale or other disposition may result in such a shortage, or (2) if such food or food product is needed to supply the normal demands of consumers in the United States."

${ }_{4}$ See items cited in note 38 , supra. An exception for relief distribution was contained in the item in the Agriculture Appropriation Act for the fiscal year I943, but was omitted from the items for the I 944 and 1945 fiscal years.

$4^{2}$ See note 40 , supra. 
No food or food product may, of course, be exported if there is a domestic shortage or need of any such food or food product. ${ }^{43}$

${ }^{43}$ Other pertinent provisions are those provided by subsections (a) and (b) of section $2 x$ of the Surplus Property Act of 1944 , which vest responsibility for the formulation of federal policy with respect to the disposal of all surplus agricultural commodities and their products in the War Food Administrator, and by section 33 of the act, which provides for restrictions on the importation of surplus property into the United States.

These sections read as follows:

"Sec. 2I. (a) Subject to the supervision of the Board, the War Food Administrator, or his successor, shall be solely responsible for the formulation of policies with respect to the disposal of surplus agricultural commodities and surplus foods processed from agricultural commodities, which shall be administered by the disposal agency or agencies designated by the Board. Such policies shall be so formulated as to prevent surplus agricultural commodities, or surplus food processed from agricultural commodities, from being dumped on the market in a disorderly manner and disrupting the market prices for agricultural commodities.

"(b) The Board shall not exercise any of its powers under this Act with relation to disposal of surplus cotton or woolen goods except with the approval in writing of the War Food Administrator or his successor.

"Sec. 33. (a) It is the policy of this Act to prohibit, so far as feasible and necessary to carry out the objectives of this Act, the importation into the United States of surplus property sold abroad or for export. The Board shall prescribe regulations to carry out such policy, and the importation of surplus property into the United States is hereby prohibited to the extent specified in such regulations. The Secretary of the Treasury is authorized and directed to provide for the enforcement of such regulations.

"(b) Surplus" property sold to members of the armed forces abroad may be brought into the United States without regard to the provisions of subsection (a) if brought in by the original purchaser and upon certificate by him that he is bringing the property into the United States for his personal use."

See also remarks of Representative Whittington in explanation of the export provisions of the act, 9o Cong. Rec., Sept. I8, I944, at 7963 . 